\title{
Brain Drain from Pakistan: Problem or Opportunity
}

\section{Mohammad Salih Memon}

Assistant Professor, Course Instructor,Department of Business Administration Shah Abdul Latif University

Khairpur

saleh.memon@salu.edu.pk

Shabana Jamil

Student of M. Phil, Department of Business Administration Shah Abdul Latif University Khairpur shabanajameel205@gmail.com

Abrar Malik

Student of M. Phil, Department of Business Administration Shah Abdul Latif University Khairpur

\section{Abstract}

Study was conducted to check the Brain Drain as an opportunity or Problem by using Remittances as the result of brain drain and economic variables of GDP, Per Capita Income, and Public Debt was used in the analysis to check the effect by using multiple regression which states that overall model is fit and independent variables are rightly predicting the dependent variables and concluded that brain drain proved to be an opportunity for the government of Pakistan for improving the economic position.

\section{Council for Innovative Research}

Peer Review Research Publishing System

\section{Journal: INTERNATION JOURNAL OF COMPUTERS AND TECHNOLOGY}

Vol. 13, No. 5

editorijctonline@gmail.com

www.cirworld.org/journals 


\section{Introduction}

The economy of Pakistan is experiencing the longest of the spell of its growth through the year. The result of different fiscal years is indicating positive sign. The economy of Pakistan performs impressively throughout the periods and its economic objectives have gained more strength.

On the other hands the prices of some food items were not stable as compared to previous years, for example: moon pulls, sugar, chicken, potatoes. This is the biggest challenge for the Government of Pakistan to maintain balance between the demand and supply of these communities by increasing production, in broader aspects domestically produced are of the major concerned, which will lead to the ultimate's talk of gross domestic product, according to the researches assumption is the level of income specifically for individuals must be maintained. Policy makers and government also of the opinion to decreased the level of poverty governments are launching different types of programs for public welfare and growth of economy as well, but major issues of random fluctuating and their impact of the smooth functioning of economy such as political instability less control over policy implementation in the result of those governments are facing different types of situation, three amongst are:

\section{Per Capita Income.}

2. Gross Domestic Production.

3. Public Debt.

4. Economic Shocks.

Economic shocks arise due to different types of situation in the perspective of Pakistan, we mean to say law and order situations, lack of interest of government in enhancing the productive activity (specifically jobs creations) and the burden of public debt may also be the reason of less interest are low investment attention of government for their public.

For all above reasons graduates, on-graduates and most of the young generation are of the opinion to switched off the Pakistan for better employments of opportunities, this will lead to the discussion of failure or success of policy makers in creation/providing employments opportunities for their public, if most of the people, academician, doctors, engineers and non-professionals are switching abroad for earning purpose and sending back their native place(parents and family) researchers are keen interest for checking the effects of remittance on major three economic variable.

\section{Per Capita Income \\ 2. Gross Domestic Production \\ 3. Public Debt}

\section{Literature Review}

According to (Haque \& Chandio, 2013) public administration play a key role in controlling the different government activities at different level of government the flight of human assets from the Pakistan is not only effect HR department but on the overall economic development of the country and concluded that government must take immediate action to minimize the disturbance among the unemployed skilled employees, and trying to draw the attention of government and policy makers in managing the human resource within the country, and proposed strategies(short term, long term)to resolve the issue of brain drain.

Granting to the researcher they said "Push" and "pull' phenomena exist everywhere in the universe. And People are forced out to leave their homes to other lands in search of safer living. Unemployment and poverty are the basic reason to leave their country. Both skilled and unskilled labor force is transferred to the developed nations for the good life. In research they find out those factors that attract the helpless people for migration, and know about the impact of emigration for both countries. It is useful for the minds of policy makers, and leaders of the nation, committing to ensure quality of animation for their masses in the street. They conclude that push factors are not eliminated, at least these may be minimized through providing appropriate education, developed infrastructure, create job opportunities, provide security for all aspects. These factors can be stopped a brain drain. Migrated people face a lot of challenges like laws are strict, expenses high, adjust in a new environment. . These events may, therefore, be taken up at high levels of the governments to review the existing immigration and foreign policies (Khan, Khan, \& Yoris, 2012).

The research(Arouri, Yahya, Shahbaz, \& Teulon, 2014) highlights the macroeconomic drivers of brain drain in Pakistan during the period in 1972-2012. They found that economic growth and financial development had a negative impact on brain drain. However brain drains due to inflation, unemployment and trade openness. And to bring the attention of policy maker to control the brain drain in Pakistan. They find out economic development and most important financial development leads industrialization and control the mind drain. The research revealed the inflation is the worst condition in brain drain, unemployment is positively linked and increase in brain drain due trade openness. The government wants to invest in agriculture and industrial sector to reduce a unemployment and control the inflation rate, must solve Administrative and the law and order issues, and to promote the foreign investments. Government must design a comprehensive trade policy to overcome the migration of skilled and unskilled person from Pakistan.

According to (Yu \& Piew, 2013) talent play a most important role in the development of economic system, and the network built among the resource crucial for national fight. Talent is highly nomadic; a most talented individual tends to indicate a higher propensity to act in reaction to better economic chances. to stop this practice researcher found out the nature and practices of academic networking and the challenges in organizing and sustaining the network. They conclude that 
coordination among their fellow workers, local or international researchers improve the quality, efficiency and effectiveness of their research work and teaching performance, to provide an adequate funding to the universities to enhance scientific collaboration and networking. The bureaucratic and rigid system often drives away potential collaborators and the desire to involve in networking activities.

(Ahmed, Hussain, Sial, Hussain, \& Akram, 2008)Income inequalities and poverty are the principal reasons of international migration. This report looked into the determinants of international migration in Pakistan. The analysis brought out that the migration from Pakistan was found positively related with inflation and unemployment rate in the nation and was negatively linked with the real wage rate. These were push factors of international migration from Pakistan and the inflow of remittance was the twist factor for out migration.

Official estimation of OverseasEmployment Corporation about 30 years back that approximately 36000 skilled professional from different fields shifted to other countries and according to current fact and figure number is around 45000(Abid, 2012).

The current equal opportunity crises in the country has effect on employees and recruit on a greater scale on overall economic level (Nadeem \& Ashfaque, 2004)

HRM Model of Harvard was looking at the employee as resource, they are viewed that it is fundamentally different from other resources. According to this model employees cannot be managed in the way as other resources of the organization (David, 1997).

The determinants of more important about the migration of technology experts and scientist is the lack of resources to carry on the research and their package level for different researchers in the recipients countries and these things are facilitating the expert and scientist .unfortunately funds are very meager in developing countries allocated for that reason, which always leads to waste of talent(Abbas, 2009).

Highly skilled workforce in developing countries is getting salaries 30 to 40 times more than in Pakistan. People who are migrating abroad their priority is not only money but self-respectmatters(HRD, 2008).

The Gallup survey of Pakistan workers from all the level of skill are losing the faith on the economic future of the country, and survey indicates the that, semi skill and unskilled workers wants to quit outside in the search of better employment opportunity(Abbas, 2009).

\section{Methodology}

Data collected from the ministry of finance government of Pakistan on the variables of Remittances (Dependent Variable) GDP, Per Capita Income, Public Debt as a (Independent Variable), from 2007-08 to 2012-13, and used in SPSS.16 through linear regression to check the interrelationship between the variables.

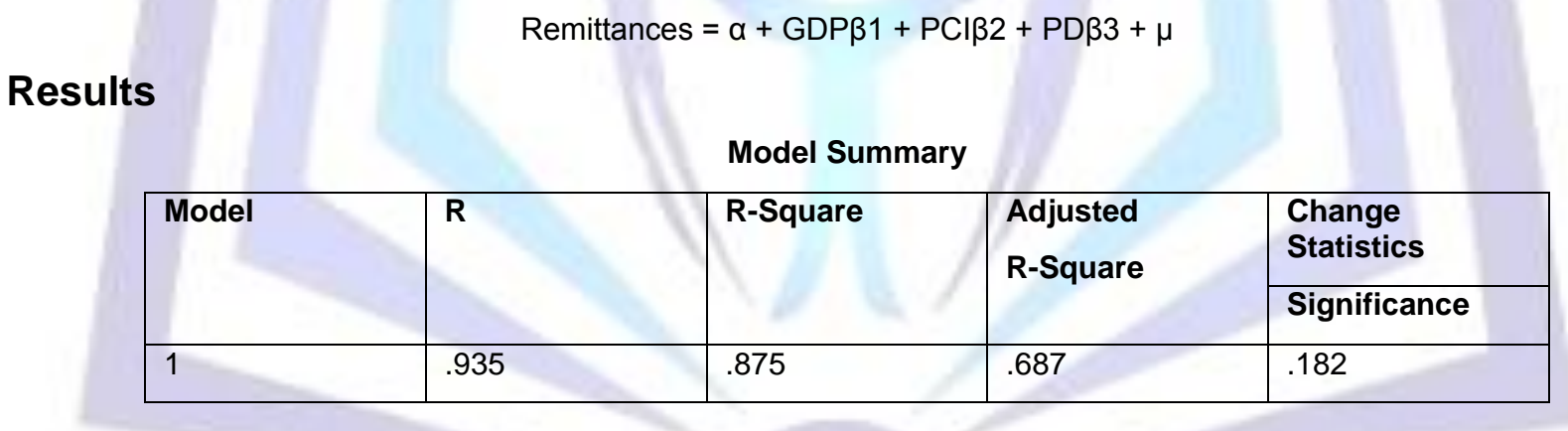

The value of R-Square is equal to. $\mathbf{8 7 5}$ which states that model is fit and the variables entered in the equation namely GDP, Per Capita Income, and Public Debt is rightly identifying the Remittances (Dependent Variable), means the power of regression equation is strong.

\section{Coefficients}

\begin{tabular}{|l|c|c|c|c|c|}
\hline \multirow{3}{*}{ Model } & \multicolumn{2}{|c|}{$\begin{array}{c}\text { Unstandardized } \\
\text { Coefficients }\end{array}$} & $\begin{array}{c}\text { Standardized } \\
\text { Coefficients }\end{array}$ & & \\
\cline { 2 - 4 } & B & Std. Error & Beta & t & Significance \\
\hline Constant & -7519.210 & 48719.322 & & -.154 & .892 \\
GDP & .009 & .011 & 1.975 & .813 & .501 \\
PCI & -1.138 & 2.398 & -.652 & -.475 & .682 \\
PD & -.006 & .016 & -.457 & -.350 & .760 \\
& & & & & \\
\hline
\end{tabular}

$\mathrm{DP}=$ Gross Domestic Production, $\mathrm{PCl}=$ Per Capita Income, $\mathrm{PD}=$ Public Debt 


\section{Conclusion}

while looking at the results given in the model summary the value of R-Square states the model fit means the variables entered in the regression equation were rightly predicting the dependent variable, and the table of coefficients is showing the interrelation and the degree of association of independent variable with the dependent variable which states that: GDP is positively and strongly associated with the remittances, means GDP will be the reason for enhancement in remittances, again it is a good sign and an opportunity for increasing the remittances we must concentrate on enhancement of GDP. Furthermore per capita income is negatively associated with the remittances which states that decrease in per capita income will be the reason of increase in remittances means the brain drain. Finally the public debt, which is also negatively associated with the remittances, when the amount of public debt is increasing the remittances, will be lowered and vice versa means when public debt is decreasing the remittances will be increased again it is opportunity for the Pakistan by decreasing the public debt on other hand increase in the remittances, finally it is concluded that the remittances are the result of Brain Drain is an opportunity for Pakistan to improve the economic situation.

\section{References}

1. Abbas, Z. (2009). Pakistan Faces Brain Drain. World South Asia, Friday 17 November.

2. Abid, A. A. (2012). Pakistan the Worst-hit Country by Brain Drain. Daily Times Monday 28- May.

3. Ahmed, N., Hussain, Z., Sial, M., Hussain, I., \& Akram, W. (2008). Macroeconomic Determinents of International Migration from Pakistan. Pakistan Economic and Social Review 46(2) Winter, 85-99.

4. Arouri, M., Yahya, R., Shahbaz, M., \& Teulon, F. (2014). Short and Long Determinents of Brain Drain: Evidence from Pakistan. http://www.ipag.fr/fr/accueil/la-recherche/publication-WP.html, 1-12.

5. David, U. (1997). Human Resource Management. Harvard Business School Press.

6. Haque, S. U., \& Chandio, J. A. (2013). Human Capital Flight in Pakistan: Strategies for Coping Brain Drain Situations. International Journal of Economics Business and Management Studies 2(2), 75-82.

7. HRD. (2008). Human Resource Development Report. www.pakistan.gov.pk.

8. Khan, R., Khan, S., \& Yoris, E. Z. (2012). Causes and Impact of Migration on Pakistani Young People on Pakistan and on Host Country (Great Britian). European Journal of Business and Social Sciences 1(8), 91-98.

9. Nadeem, N., \& Ashfaque, M. (2004). Brain Drain in Pakistan. Government of Pakistan.

10. Yu, C. M., \& Piew, T. H. (2013). Brain Drain Talent Mobility and Academic Networking. International Conference on Human Management Organized by School of Business and Economics February 27-28, 2013.

\section{Author's Biography}

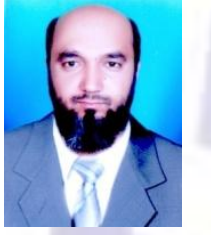

"Completed my MBA from Shah Abdul Latif University Khairpur, Sindh Pakistan in Finance and appointed as lecturer there in september 2004 and completed my M. Phil in Finance from IQRA University Karachi in 2010 and promoted as Assistant Professor, now recently submitted my Ph.D thesis for foreign evaluation from Shah Abdul Latif University Khairpur in Public finance under the supervision of Dr. Syed Munir Ahmed Shah". 